\title{
Clinical and Immunological Factors Associated with Postpartum Hepatic Flares in Immune-Tolerant Pregnant Women with Hepatitis B Virus Infection Treated with Telbivudine
}

\author{
Junfeng $\mathrm{Lu}^{1}$, Xiaoxiao Wang1, Yunxia Zhu², Lina Ma1, Sujun Zheng ${ }^{1}$, Zhongjie $\mathrm{Hu}^{1}$, and Xinyue Chen ${ }^{1}$ \\ ${ }^{1}$ First Department of Liver Disease, and ${ }^{2}$ Department of Obstetrics and Gynecology, Beijing Youan Hospital, Capital Medical University, \\ Beijing, China
}

\section{Article Info}

Received December 22, 2020

Revised May 12, 2021

Accepted May 13, 2021

\section{Corresponding Author}

Xinyue Chen

ORCID https://orcid.org/0000-0003-3212-2398

E-mail chenxydoc@ccmu.edu.cn

\begin{abstract}
Background/Aims: To investigate postpartum hepatic flares and associated factors in highly viremic pregnant patients in the immune tolerance phase who adopted telbivudine (LdT) treatment in the last trimester to reduce vertical transmission of hepatitis $B$ virus.

Methods: Hepatitis B e antigen ( $\mathrm{HBeAg}$ )-positive, highly viremic pregnant women were recruited for this prospective study. Treatment with LdT was started from 28 weeks of gestation. Virological and biochemical markers were examined before LdT treatment, antepartum and postpartum. Serial blood samples at the same time were collected to detect cytokines and cortisol (COR).

Results: Fifty-six of 153 patients (36.6\%) had postpartum hepatic flares, defined as a 2-fold increase in alanine aminotransferase 6 weeks after delivery. Age and the antepartum alanine aminotransferase and postpartum HBeAg levels were independent influencing factors of postpartum hepatic flares. Cytokines showed no regularity during or after pregnancy. Compared with the patients with no postpartum flares, the patients with flares had lower baseline interferon $\gamma$ and COR levels $(p=0.022$ and $p=0.028)$ and higher postpartum interferon $\gamma$ levels $(p=0.026)$.

Conclusions: A high proportion of highly viremic and immune-tolerant pregnant patients treated with LdT in the last trimester had postpartum hepatic flares, which implied that these patients entered the immune clearance phase after delivery. Thus, this may create an appropriate opportunity for re-antiviral therapy. (Gut Liver 2021;15:887-894)
\end{abstract}

Key Words: Postpartum; Hepatic flares; Immune tolerance; Pregnancy; Hepatitis B

\section{INTRODUCTION}

Mother-to-infant transmission is the leading mode of hepatitis B virus (HBV) infection in China. ${ }^{1}$ Although the combination of hepatitis $B$ vaccine and immunoglobulin in preventing vertical transmission has achieved great success, HBV perinatal transmission in highly viremic mothers remains a major challenge. Up to $8 \%-15 \%$ of infants born to highly viremic mothers still become infected with $\mathrm{HBV}^{2-4}$ Several studies have shown that antiviral therapy with nucleos $(\mathrm{t})$ ide analogue (NA) in the third trimester of pregnancy could reduce the risk of perinatal HBV transmission in highly viremic mothers. ${ }^{5,6}$ This antiviral intervention in late pregnancy is mainly aimed at pregnant women with immune tolerance phase characterized by high levels of hepatitis B e antigen (HBeAg) and HBV DNA and little or no elevation in liver transaminases. However, aminotransferase increased and/or HBeAg decreased after pregnancy has been observed in some patients with chronic hepatitis $\mathrm{B}(\mathrm{CHB}))^{7-9}$ Studies related to the changes of virological and biochemical markers during and after pregnancy are limited, especially postpartum hepatic flares in highly viremic immune-tolerant pregnant patients treated with analogue in the third trimester.

Furthermore, HBV is a non-cytopathic virus and host immune response plays a key role in liver injury and virus control. ${ }^{10}$ Immunological changes during and after pregnancy may impact on the natural history and clinical 
manifestations of chronic HBV infection. ${ }^{11}$ It has been speculated that reactivation of the immune function was associated with postpartum hepatic flares. However, the exact immunological influencing factors are still uncertain.

The purpose of this study was to evaluate virological and biochemical changes during and after pregnancy and explore the clinical and immunological associated factors with the postpartum hepatic flares by a cohort of highly viremic immune-tolerant pregnant patients with telbivudine (LdT) treatment in the third trimester.

\section{MATERIALS AND METHODS}

\section{Patients}

This was a prospective study. All the patients were from Beijing Youan Hospital between year 2015 and 2017. Patients with HBV DNA $\geq 1.0 \times 10^{6} \mathrm{IU} / \mathrm{mL}$ and HBeAg level $\geq 500$ cutoff index (more representative of the state of immune tolerance) in the second trimester of pregnancy were recruited. Patients were excluded if they had received antiviral therapy or had abnormal liver function before and during pregnancy or if they had hepatitis $\mathrm{C}$, hepatitis $\mathrm{D}$, or human immunodeficiency virus co-infection or cirrhosis. LdT therapy was started in the third trimester (28 weeks of gestation) to reduce vertical transmission and stopped immediately or continued until 6 weeks after delivery according to patient's willingness. Follow-up was conducted before LdT treatment (baseline), antepartum (36 weeks of gestation) and postpartum (6 weeks after delivery) and serial blood samples were collected at the corresponding time points. The study was approved by the Institutional Review Board of Beijing Youan Hospital, Capital Medical University (IRB No. [2019]190) and performed in accordance with the principles of the Declaration of Helsinki. Informed consent was obtained from all patients.

\section{Biochemical, virological and immunological assessments}

The liver inflammation was determined by measuring serum alanine aminotransferase (ALT) level with upper limit of normal (ULN) value being $40 \mathrm{U} / \mathrm{L}$. Serum HBeAg was determined using enzyme immunoassays. $\mathrm{HBeAg}$ was defined as positive when the concentration exceeded 1.0 cutoff index. Hepatitis B surface antigen (HBsAg) was quantified using Elecsys (Roche Diagnostics GmbH, Penzberg, Germany) with lowest detection limit of $0.05 \mathrm{IU} /$ $\mathrm{mL}$. Serum HBV DNA levels were measured using the Cobas TaqMan (Roche Diagnostics GmbH; lowest detection limit, $20 \mathrm{IU} / \mathrm{mL}$ ). Serum cytokines including interleukin (IL)-2, IL-4, IL-6, IL-10, IL-17, interferon $\gamma$ (IFN $\gamma$ ), and tumor necrosis factor $\alpha$ (TNF- $\alpha$ ) were detected using Human Cytokine Assay Kit (Bio-Rad, Hercules, CA, USA). Serum cortisol (COR) was measured by electrochemiluminescence immunoassay (COBAS E411, Roche Diagnostics $\mathrm{GmbH})$.

\section{Definition of postpartum hepatic flare}

Postpartum hepatic flare was defined as at least 2 times the ULN in ALT level at 6 weeks after delivery which referred the definition of CHB in China (2015 edition). ${ }^{12}$

\section{Statistical analysis}

Continuous variables were presented as mean \pm standard deviation or median plus interquartile range and the t-test or the Mann-Whitney U-test was used for the comparison. Categorical variables were summarized using frequency and percentage. Univariable and multivariable logistic regressions were performed to assess the clinical associated factors associated with postpartum hepatic flares. Statistical analysis was performed using SPSS software version 19.0 (IBM Corp., Armonk, NY, USA). All statistical tests were two-sided and evaluated at the 0.05 level of significance.

Table 1. Baseline Characteristics of All Subjects and of the Subgroups with and without Postpartum Hepatic Flares

\begin{tabular}{lcccc}
\hline \multicolumn{1}{c}{ Characteristic } & Overall $(n=153)$ & Postpartum flares $(n=56)$ & No postpartum flares $(n=97)$ & $p$-value \\
\hline Age, $y r$ & $28.80 \pm 3.88$ & $27.60 \pm 4.26$ & $29.50 \pm 3.49$ & 0.333 \\
ALT, U/L & $25.90 \pm 9.39$ & $27.50 \pm 9.57$ & $24.90 \pm 9.19$ & 0.959 \\
Genotype & & & & \\
$\quad$ C & $110(71.9)$ & $39(69.6)$ & $71(73.2)$ & \\
B & $42(27.4)$ & $16(28.6)$ & $26(26.8)$ & 0 \\
A & $1(0.6)$ & $1(1.8)$ & $4.36 \pm 0.39$ & 0.633 \\
HBsAg, log IU/mL & $4.31 \pm 0.48$ & $4.24 \pm 0.54$ & $3.12 \pm 0.12$ & 0.581 \\
HBeAg, log COI & $3.14 \pm 0.12$ & $3.16 \pm 0.11$ & $7.87 \pm 0.49$ & 0.030 \\
HBV DNA, log IU/mL & $7.84 \pm 0.53$ & $7.78 \pm 0.60$ & & \\
\hline
\end{tabular}

Data are presented as mean \pm SD or number $(\%)$.

ALT, alanine aminotransferase; HBsAg, hepatitis B surface antigen; HBeAg, hepatitis B e antigen; COI, cutoff index; HBV, hepatitis B virus. 


\section{RESULTS}

\section{Baseline characteristics}

Between 2015 and 2017, 158 women were recruited into this study. Five women were excluded due to ALT elevation during pregnancy and 153 women were included in the final analysis. The baseline mean age was $28.8 \pm 3.88$ years, and ALT values were in normal range with a mean value of 25.9 $\pm 9.39 \mathrm{U} / \mathrm{L}$. All the patients were in the immune tolerance phase with a high level of baseline HBV DNA, HBsAg and $\mathrm{HBeAg}$ (Table 1). One hundred and ten out of 153 patients (71.9\%) were genotype $\mathrm{C}$, followed by genotypes $\mathrm{B}$ and A. No obvious adverse reactions were observed in the pregnant women treated with LdT and no significant difference was noted with respect to weight, height, or Apgar score in the newborns.

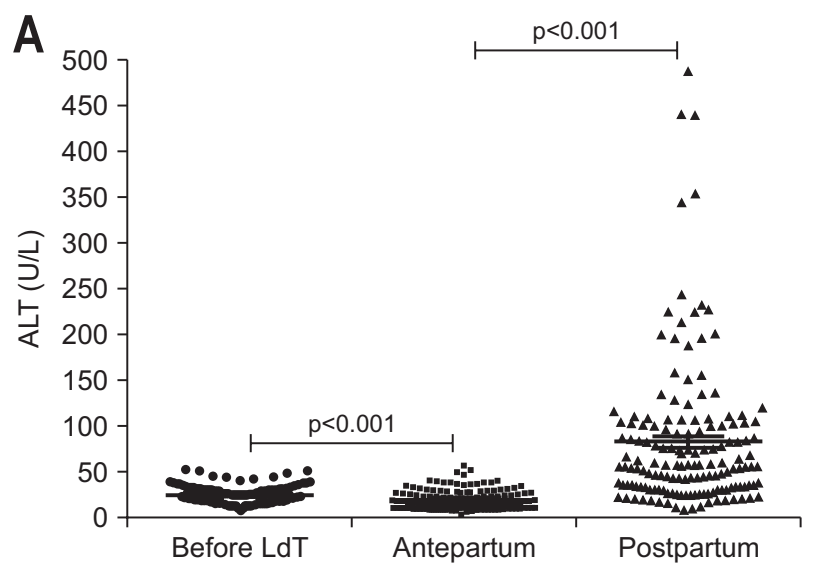

\section{Changes of the biochemical and virological markers during and after pregnancy}

Although ALT levels were in normal range during pregnancy in these patients, there was a declining tendency over pregnancy. ALT decreased at the antepartum compared with the baseline $(\mathrm{p}<0.001)$ and increased significantly after delivery compared with during pregnancy $(\mathrm{p}<0.001)$ (Fig. 1A). Fifty-six out of 153 patients (36.6\%) showed postpartum hepatic flares (defined as ALT $\geq 2 \times \mathrm{ULN}$ at 6 weeks after delivery) with the maximum ALT of more than $10 \times \mathrm{ULN}$, and only 51 out of 153 patients $(33.3 \%)$ maintained ALT within normal range after delivery. None of the postpartum ALT increase led to an increase in bilirubin or decompensated liver function. LdT therapy was stopped immediately in 103 patients and continued until 6 weeks in 50 patients after delivery and there

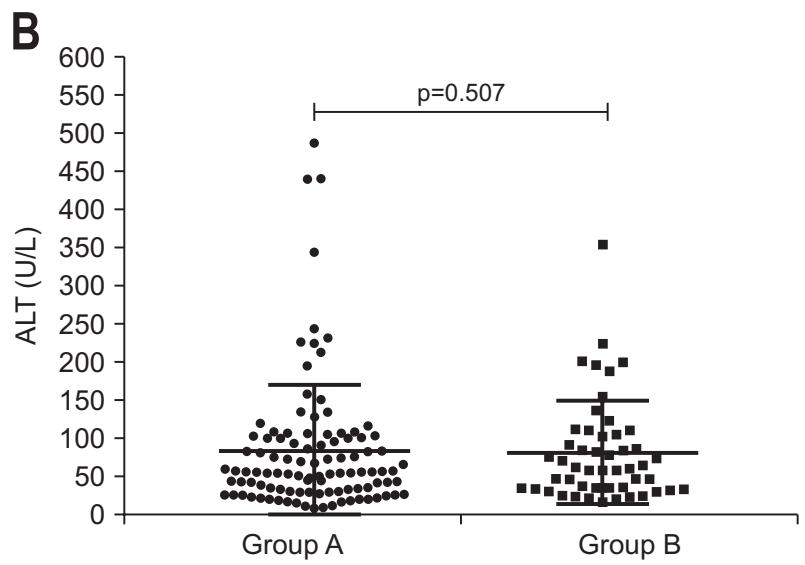

Fig. 1. Changes in aminotransferase (ALT) levels before and after delivery. (A) Changes in alanine ALT levels at baseline, antepartum and postpartum in all the patients. (B) Postpartum ALT levels in those who stopped telbivudine (LdT) immediately after (group A, n=103) or 6 weeks after delivery (group $B, n=50)$.
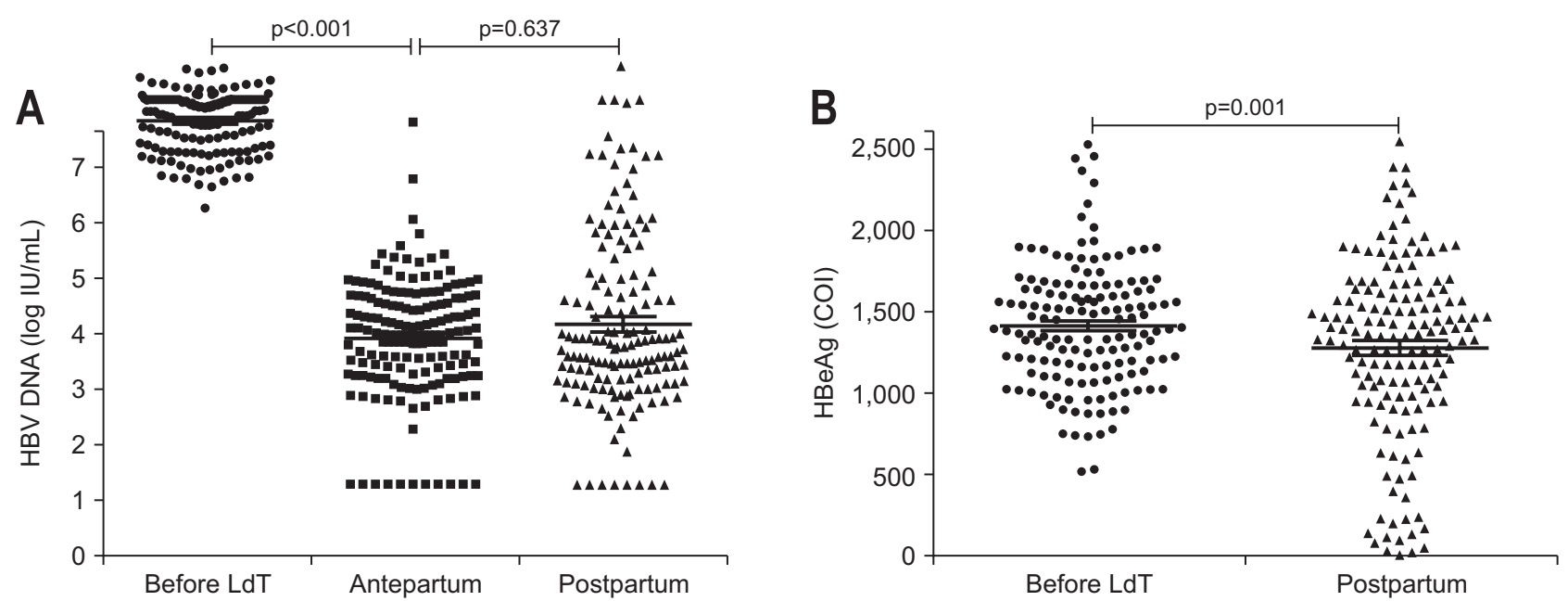

Fig. 2. Virological changes before and after delivery. (A) Changes in HBV DNA levels before LdT, antepartum and postpartum. (B) Changes in HBeAg levels before LdT and postpartum.

HBV, hepatitis B virus; LdT, telbivudine; HBeAg, hepatitis B e antigen; COI, cutoff index. 
Table 2. Clinical Factors Associated with Postpartum Hepatic Flares

\begin{tabular}{|c|c|c|c|c|c|c|}
\hline \multirow{2}{*}{ Clinical factor } & \multicolumn{3}{|c|}{ Univariate logistic analysis } & \multicolumn{3}{|c|}{ Multivariate logistic analysis } \\
\hline & B & p-value & OR $(95 \% \mathrm{CI})$ & B & $\mathrm{p}$-value & $\mathrm{OR}(95 \% \mathrm{Cl})$ \\
\hline Age & -0.131 & 0.005 & $0.877(0.772-0.976)$ & -0.138 & 0.006 & $0.871(0.763-0.962)$ \\
\hline Genotype & 0.314 & 0.380 & 1.369 (0.594-3.188) & 0.007 & 0.987 & $1.007(0.125-2.704)$ \\
\hline Baseline ALT & 0.030 & 0.100 & $1.030(0.955-1.057)$ & 0.005 & 0.840 & 1.005 (0.932-1.048) \\
\hline Baseline $\mathrm{HBeAg}$ & 0.001 & 0.061 & $1.001(0.996-1.008)$ & 0.003 & 0.000 & $1.003(1.001-1.010)$ \\
\hline Baseline HBsAg & 0.217 & 0.603 & $1.721(0.369-4.272)$ & 0.056 & 0.942 & $1.164(0.104-3.607)$ \\
\hline Baseline HBV DNA & -0.313 & 0.323 & $0.731(0.358-1.246)$ & -0.395 & 0.298 & $0.673(0.302-1.217)$ \\
\hline Antepartum ALT & 0.061 & 0.001 & $1.063(1.027-1.101)$ & 0.047 & 0.032 & $1.048(1.012-1.079)$ \\
\hline Antepartum HBV DNA & 0.169 & 0.274 & $1.184(0.865-1.596)$ & -0.093 & 0.647 & $0.911(0.565-1.264)$ \\
\hline Postpartum HBeAg & 0.000 & 0.006 & 0.999 (0.998-1.000) & -0.002 & 0.000 & 0.998 (0.996-0.999) \\
\hline Postpartum HBsAg & 0.179 & 0.231 & $1.557(0.287-3.906)$ & 0.216 & 0.683 & $1.028(0.131-3.284)$ \\
\hline Postpartum HBV DNA & 0.079 & 0.446 & 1.083 (0.883-1.328) & 0.142 & 0.283 & $1.153(0.931-1.405)$ \\
\hline
\end{tabular}

OR, odds ratio; $\mathrm{Cl}$, confidence interval; $\mathrm{ALT}$, alanine aminotransferase; HBeAg, hepatitis B e antigen; HBsAg, hepatitis B surface antigen; HBV, hepatitis $B$ virus.
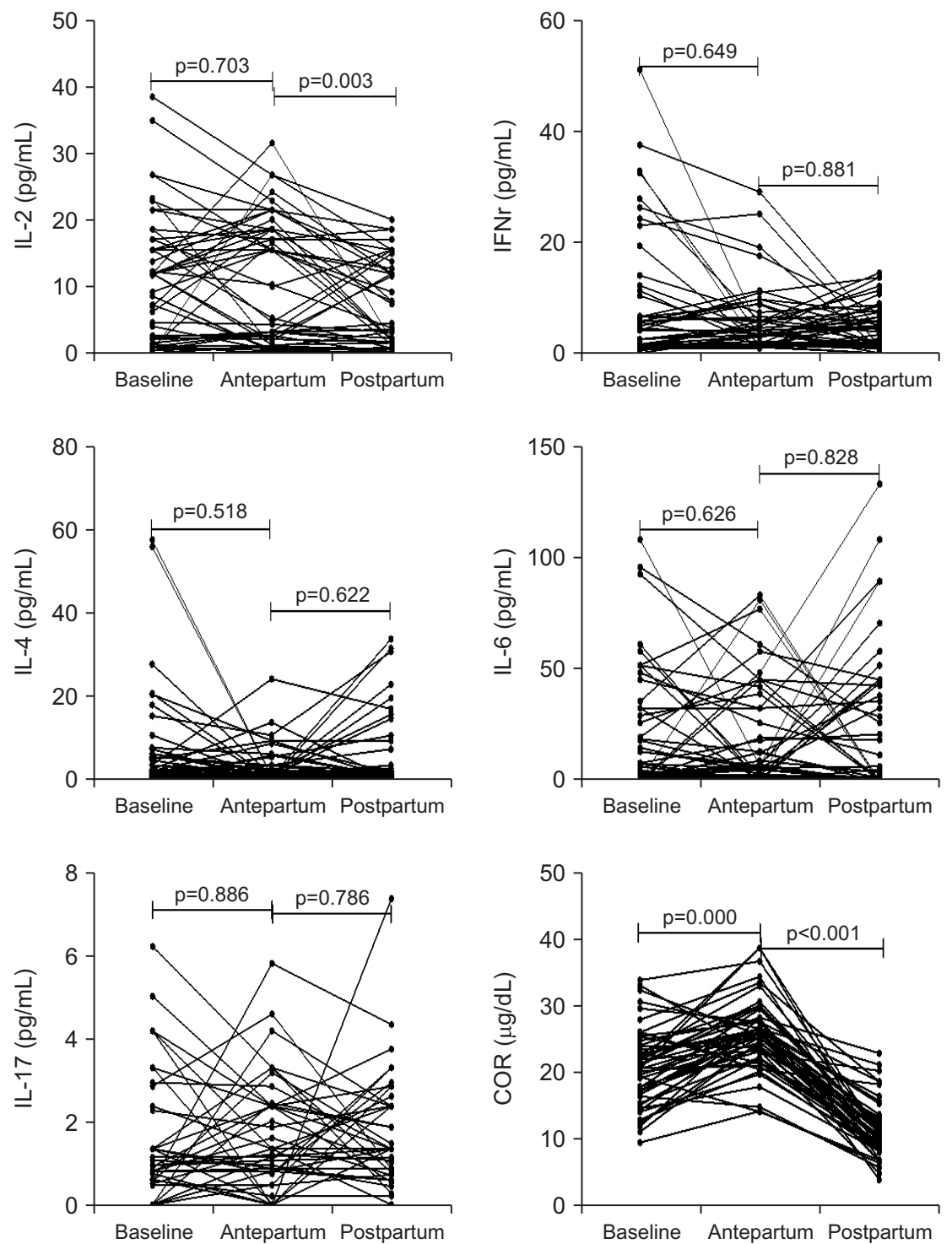
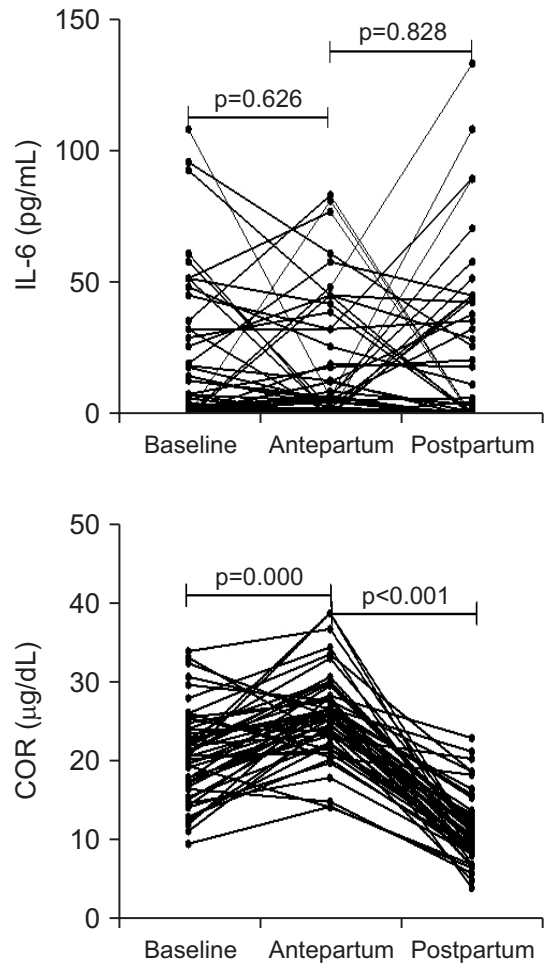
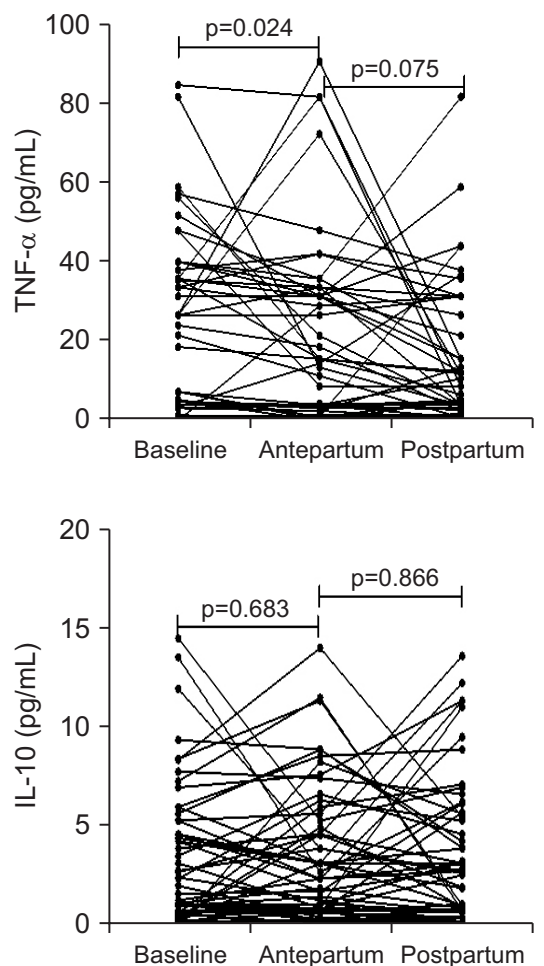

Fig. 3. Changes in cytokines and COR at baseline, antepartum and postpartum.

IL, interleukin; IFN, interferon; TNF, tumor necrosis factor; COR, cortisol. 
Table 3. Immunological Factors Associated with Postpartum Hepatic Flares

\begin{tabular}{|c|c|c|c|}
\hline Factor & Postpartum flare $(n=15)$ & No postpartum flare $(n=37)$ & $\mathrm{p}$-value \\
\hline \multicolumn{4}{|l|}{ Baseline } \\
\hline IL-2, pg/mL & $10.83 \pm 7.62$ & $12.59 \pm 12.33$ & 0.190 \\
\hline $\mathrm{IL}-4, \mathrm{pg} / \mathrm{mL}$ & 2.52 (1.65-11.09) & $1.33(0.56-5.66)$ & 0.233 \\
\hline IL-6, pg/mL & $3.39(1.20-52.13)$ & $8.28(1.19-31.43)$ & 0.793 \\
\hline IL-10, pg/mL & $3.33 \pm 3.75$ & $3.60 \pm 3.50$ & 0.983 \\
\hline IL-17, pg/mL & $1.21(0.08-3.00)$ & $1.08(0.67-2.43)$ & 0.783 \\
\hline $\mathrm{IFN} \gamma, \mathrm{pg} / \mathrm{mL}$ & 1.89 (1.31-6.98) & $5.39(2.09-16.12)$ & 0.022 \\
\hline $\mathrm{TNF}-\alpha, p g / \mathrm{mL}$ & 26.75 (1.62-40.18) & $21.69(4.16-35.80)$ & 0.927 \\
\hline $\mathrm{COR}, \mu \mathrm{g} / \mathrm{dL}$ & $20.19 \pm 7.67$ & $20.97 \pm 4.65$ & 0.028 \\
\hline \multicolumn{4}{|l|}{ Antepartum } \\
\hline $\mathrm{IL}-2, \mathrm{pg} / \mathrm{mL}$ & $9.43 \pm 8.29$ & $11.93 \pm 9.79$ & 0.143 \\
\hline $\mathrm{IL}-4, \mathrm{pg} / \mathrm{mL}$ & $2.36(0.71-9.79)$ & 1.43 (1.22-3.95) & 0.635 \\
\hline $\mathrm{IL}-6, \mathrm{pg} / \mathrm{mL}$ & $2.45(0.55-7.99)$ & $7.45(1.18-44.20)$ & 0.056 \\
\hline $\mathrm{IL}-10, \mathrm{pg} / \mathrm{mL}$ & $3.45 \pm 3.10$ & $4.37 \pm 4.80$ & 0.244 \\
\hline $\mathrm{IL}-17, \mathrm{pg} / \mathrm{mL}$ & $1.30 \pm 1.07$ & $1.85 \pm 1.44$ & 0.298 \\
\hline $\mathrm{IFN} \gamma, \mathrm{pg} / \mathrm{mL}$ & $3.51(2.01-6.17)$ & 3.79 (1.89-8.08) & 0.856 \\
\hline $\mathrm{TNF}-\alpha, \mathrm{pg} / \mathrm{mL}$ & $19.36 \pm 21.75$ & $21.82 \pm 23.32$ & 0.639 \\
\hline COR, $\mu \mathrm{g} / \mathrm{dL}$ & $25.26 \pm 6.22$ & $26.09 \pm 4.88$ & 0.436 \\
\hline \multicolumn{4}{|l|}{ Postpartum } \\
\hline IL-2, pg/mL & $9.50(2.07-15.75)$ & $3.58(1.26-13.53)$ & 0.390 \\
\hline $\mathrm{IL}-4, \mathrm{pg} / \mathrm{mL}$ & $3.22(1.21-19.99)$ & $1.61(1.07-3.58)$ & 0.079 \\
\hline $\mathrm{IL}-6, \mathrm{pg} / \mathrm{mL}$ & $2.28(0.96-45.79)$ & $1.56(0.52-31.17)$ & 0.241 \\
\hline $\mathrm{IL}-10, \mathrm{pg} / \mathrm{mL}$ & $3.18(1.06-9.50)$ & $2.90(0.71-5.69)$ & 0.298 \\
\hline IL-17, pg/mL & $1.69 \pm 0.94$ & $1.82 \pm 1.56$ & 0.175 \\
\hline $\mathrm{IFN} \gamma, \mathrm{pg} / \mathrm{mL}$ & 6.18 (2.96-8.95) & $2.55(1.78-6.58)$ & 0.026 \\
\hline$T N F-\alpha, p g / m L$ & $12.10(4.58-31.50)$ & 5.57 (2.79-21.29) & 0.185 \\
\hline $\mathrm{COR}, \mu \mathrm{g} / \mathrm{dL}$ & $11.48 \pm 4.46$ & $11.34 \pm 4.03$ & 0.595 \\
\hline
\end{tabular}

Data are presented as mean $\pm \mathrm{SD}$ or median (IQR).

IL, interleukin; IFN, interferon; TNF, tumor necrosis factor; COR, cortisol; IQR, interquartile range.

was no significant difference in ALT level between the two groups (Fig. 1B).

HBV DNA loads declined significantly at the antepartum compared with the baseline ( $\mathrm{p}<0.001)$ (Fig. $2 \mathrm{~A})$. One hundred and twenty out of 153 patients (78.4\%) achieved more than $3 \log \mathrm{IU} / \mathrm{mL}$ decrease in HBV DNA level and 11 out of $153(7.2 \%)$ had undetectable HBV DNA levels $(<20$ $\mathrm{IU} / \mathrm{mL}$ ) at the antepartum. There was no significant difference in HBV DNA level between antepartum and postpartum due to LdT withdrawal immediately after delivery in some patients.

The HBeAg level also decreased significantly after delivery compared with the baseline ( $\mathrm{p}=0.001)$ (Fig. 2B). Although no HBeAg seroclearance was observed, 21 out of 153 patients (13.7\%) had more than $80 \%$ decrease in HBeAg level after delivery. The change of HBsAg level between the baseline and postpartum was not statistically significant (data not shown).

\section{Clinical associated factors related to postpartum hepatic flares}

As mentioned above, 56 patients (36.6\%) met the definition of a postpartum hepatic flare. The characteristics of the subjects at baseline are shown in Table 1. Mean HBV DNA level in the patients with postpartum hepatic flares was significantly lower than patients without hepatic flares $(\mathrm{p}=0.030)$. Univariable and multivariable logistic analysis showed that age, antepartum ALT level, and postpartum $\mathrm{HBeAg}$ level were independent influencing factors of postpartum hepatic flares (Table 2). HBV DNA level at baseline was no longer significant statistically. Receiver operating characteristic curves of the age, antepartum ALT, and postpartum $\mathrm{HBeAg}$ level in predicting postpartum hepatic flares were drawn. Area under the curves was $0.682,0.711$ and 0.635 respectively and the corresponding cutoff value was $29,14.8$ and 3.1. The patients below 29 years old, with ALT greater than $14.8 \mathrm{U} / \mathrm{L}$ and postpartum HBeAg level below 3.1 log cutoff index had a higher risk of postpartum hepatic flares.

\section{Immunological associated factors related to postpartum hepatic flares}

Serum COR and cytokines were measured in 52 out of the 153 patients at baseline, antepartum, and postpartum. Serum COR levels increased at the antepartum and decreased after delivery significantly. IL-2 levels declined 
significantly after delivery compared with the antepartum $(\mathrm{p}=0.003)$ and TNF- $\alpha$ levels at the antepartum was higher compared with the baseline ( $\mathrm{p}=0.024)$. The other serum cytokines, including IFN $\gamma$, IL-4, IL-6, IL-10, and IL-17 were not significantly different among baseline, antepartum, and postpartum (Fig. 3).

Similarly, according to the postpartum ALT level, the patients were divided into postpartum flares and no postpartum flares (ALT $\geq 2 \times U L N$ and $<2 \times U L N$ ). Compared with the patients with no postpartum flares, the levels of IFN $\gamma$ and COR were significantly lower at baseline $(\mathrm{p}=0.022$ and $\mathrm{p}=0.028$, respectively) and IFN $\gamma$ level was significantly higher after delivery $(\mathrm{p}=0.026)$ in the patients with postpartum hepatic flares (Table 3). Lower baseline IFN $\gamma$ and COR levels, higher postpartum IFN $\gamma$ levels were associated significantly with postpartum hepatic flares.

\section{DISCUSSION}

With the recommendation of the latest guidelines, more and more highly viremic immune-tolerant pregnant women adopted NA therapy in the third trimester of pregnancy. ${ }^{12-14}$ The aim of NA therapy was to reduce the risk of vertical transmission, not to treat the pregnant women themselves. However, there is no consensus on how to deal with antiviral therapy for these patients after delivery. We previously showed that high rates of serological clearance/ conversion could be achieved in some immune-tolerant pregnant women who had postpartum hepatic flares and were re-treated by peginterferon based regimen after childbirth. ${ }^{15}$ Therefore, to further clarify the changes of the biochemical and virological markers during and after pregnancy and associated factors related to postpartum hepatic flares may provide a guidance for the antiviral strategies after delivery in these patients.

In this large prospective study, remarkable biochemical and virological changes were observed in these patients during and after pregnancy. HBV DNA level decreased more than $3 \log \mathrm{IU} / \mathrm{mL}$ in $78.4 \%$ of the patients in a short period, which indicated that the antiviral therapy was effective in the immune-tolerant pregnant patients. ALT $\geq 2 \times$ ULN occurred in $36.6 \%$ of the patients after delivery, which was similar to the result of previous studies reporting postpartum flares in $25 \%$ to $50 \%$ of $\mathrm{CHB}$ patients. ${ }^{7,9,16}$ ALT increase at the lower HBV DNA level after childbirth reflected the recovery of maternal immune function and should be paid attention to in clinical practice. Age, antepartum ALT and postpartum HBeAg level were three important clinical factors related to postpartum hepatic flares. During pregnancy, there were complex physiologi- $\mathrm{cal}$ and immunological changes in the maternal system to prevent rejection to the fetuses. ${ }^{17-19}$ Overall, the cellular immune function during pregnancy tends to be inhibited, ${ }^{20}$ which could explain the decline in ALT level over pregnancy. Under these circumstances, antepartum ALT increase (still in normal range) might suggest an increased immune response against the HBV and lead to postpartum hepatic flares. A prospective study has reported that $\mathrm{HBeAg}$ positivity was a strong predictor of postpartum flares and patients who were $\mathrm{HBeAg}$-positive at baseline had a higher risk of postpartum flares. ${ }^{16}$ However, in this study, although there was no $\mathrm{HBeAg}$ seroclearance, the $\mathrm{HBeAg}$ level decreased significantly after delivery and lower HBeAg level was significantly associated with postpartum hepatic flares. HBeAg was a non-particulate protein of HBV and can down regulate the immune response. ${ }^{21}$ The decrease of HBeAg level after delivery could partly reverse the immune tolerance and may better reflect the postpartum immune activation, which could be supported indirectly by higher serological responses in pregnant patients with lower postpartum HBeAg level. ${ }^{15}$ A higher rate of spontaneous HBeAg seroclearance after delivery has also been reported. ${ }^{9,22}$ About age, we speculate that the immune function is stronger in the younger women and may result in higher rate of ALT increase after pregnancy.

Immunology during pregnancy was characterized by a T helper $2\left(\mathrm{~T}_{\mathrm{H}} 2\right)$-type environment. ${ }^{23}$ In this study, although the mean value of IL-2 decreased after delivery and TNF- $\alpha$ increased at the antepartum, the change of the cytokines including $\mathrm{T}_{\mathrm{H}} 1$-type (IL-2, IFN $\gamma$, and TNF- $\alpha$ ), $\mathrm{T}_{\mathrm{H}}$ 2-type (IL-4, IL-6, and IL-10) and IL-17 during and after pregnancy showed no obvious pattern except for serum COR, which increased significantly at the antepartum and decreased after delivery. Current understanding of the immunology of pregnancy was mostly extrapolated from studies in non-pregnant models, such as organ transplantation and cancer immunology and was not completely explicit. The current view is that the maternal immune function changes and adapts constantly during pregnancy, which is generally divided into three stages: a pro-inflammatory stage associated implantation and placentation, an anti-inflammatory stage associated with fetal growth and a pro-inflammatory stage associated with labor. ${ }^{24}$ In addition, HBV infection and LdT treatment may also affect the change of the cytokines. Many researches have reported immune modulatory effects associated with LdT treatment including adaptive immunity and innate immunity. ${ }^{25-27}$

Interestingly, according to the level of ALT after delivery, stratified analysis showed that IFN $\gamma$ level at baseline and after delivery was significantly associated with postpartum hepatic flares. As we all know, IFN $\gamma$ is produced 
by activated $\mathrm{T}$ cells, natural killer cells, and natural killer $\mathrm{T}$ cells which could kill infected cells through their cytotoxicity. Successful HBV clearance was associated with $\mathrm{HBV}$-specific and IFN $\gamma+$ effector T-cell response. ${ }^{28}$ Higher production of IFN $\gamma$ was associated with $\mathrm{HBsAg}$ or $\mathrm{HBeAg}$ seroconversion in patients with $\mathrm{CHB} .{ }^{29}$ During pregnancy, the lower IFN $\gamma$ level implied that the cellular immune function was decreased and postpartum higher IFN $\gamma$ level indicated the cellular immune function was enhanced and may further lead to the increase in ALT level.

In conclusion, a high proportion of highly viremic immune-tolerant pregnant women treated with LdT in the third trimester had hepatic flares after pregnancy. This may due to postpartum reactivation of immune function. Combined with our previous study, the younger patients with hepatic flares accompanied by lower HBeAg level and higher IFN $\gamma$ level after pregnancy may be suitable for further re-antiviral therapy to achieve better response.

\section{CONFLICTS OF INTEREST}

No potential conflict of interest relevant to this article was reported.

\section{ACKNOWLEDGEMENTS}

This research was supported by China's 13th 5-year plan for Key Projects in Infectious Diseases Grant (numbers: 2017ZX10201201-001-008, 2017ZX10202201, 2017ZX10202202-005-010), the Key R \& D and transformation plan in Qinghai Province (number: 2017-SF-159), and High-level and Innovative One Thousand Talent Program in Qinghai Province (2016).

\section{AUTHOR CONTRIBUTIONS}

Study concept and design: X.C., J.L. Data acquisition: X.W., Y.Z. Data analysis and interpretation: X.W., J.L. Drafting of the manuscript: J.L. Critical revision of the manuscript for important intellectual content: S.Z., Z.H. Statistical analysis: J.L. Obtained funding: X.C., Z.H. Administrative, technical: L.M.

\section{ORCID}

Junfeng Lu https://orcid.org/0000-0003-0558-6816

Xiaoxiao Wang https://orcid.org/0000-0002-6296-496X
Yunxia Zhu

https://orcid.org/0000-0002-1047-7035

Lina Ma

Sujun Zheng

Zhongjie $\mathrm{Hu}$

Xinyue Chen

https://orcid.org/0000-0002-0867-2341

https://orcid.org/0000-0002-6367-5764

https://orcid.org/0000-0001-7313-5326

https://orcid.org/0000-0003-3212-2398

\section{REFERENCES}

1. Cui F, Luo H, Wang F, et al. Evaluation of policies and practices to prevent mother to child transmission of hepatitis B virus in China: results from China GAVI project final evaluation. Vaccine 2013;31 Suppl 9:J36-J42.

2. Wiseman E, Fraser MA, Holden S, et al. Perinatal transmission of hepatitis B virus: an Australian experience. Med J Aust 2009;190:489-492.

3. Xu WM, Cui YT, Wang L, et al. Lamivudine in late pregnancy to prevent perinatal transmission of hepatitis $B$ virus infection: a multicentre, randomized, double-blind, placebocontrolled study. J Viral Hepat 2009;16:94-103.

4. Zou H, Chen Y, Duan Z, Zhang H, Pan C. Virologic factors associated with failure to passive-active immunoprophylaxis in infants born to HBsAg-positive mothers. J Viral Hepat 2012;19:e18-e25.

5. Zhang H, Pan CQ, Pang Q, Tian R, Yan M, Liu X. Telbivudine or lamivudine use in late pregnancy safely reduces perinatal transmission of hepatitis B virus in real-life practice. Hepatology 2014;60:468-476.

6. Pan CQ, Duan Z, Dai E, et al. Tenofovir to prevent hepatitis $\mathrm{B}$ transmission in mothers with high viral load. N Engl J Med 2016;374:2324-2334.

7. ter Borg MJ, Leemans WF, de Man RA, Janssen HL. Exacerbation of chronic hepatitis B infection after delivery. J Viral Hepat 2008;15:37-41.

8. Tan HH, Lui HF, Chow WC. Chronic hepatitis B virus (HBV) infection in pregnancy. Hepatol Int 2008;2:370-375.

9. Lin $\mathrm{HH}, \mathrm{Wu}$ WY, Kao JH, Chen DS. Hepatitis B postpartum e antigen clearance in hepatitis B carrier mothers: correlation with viral characteristics. J Gastroenterol Hepatol 2006;21:605-609.

10. Rehermann B. Pathogenesis of chronic viral hepatitis: differential roles of T cells and NK cells. Nat Med 2013;19:859868.

11. Trowsdale J, Betz AG. Mother's little helpers: mechanisms of maternal-fetal tolerance. Nat Immunol 2006;7:241-246.

12. Chinese Society of Hepatology, Chinese Medical Association; Chinese Society of Infectious Diseases, Chinese Medical Association, Hou JL, lai W. The guideline of prevention and treatment for chronic hepatitis B: a 2015 update. Zhonghua Gan Zang Bing Za Zhi 2015;23:888-905.

13. European Association for the Study of the Liver. EASL 2017 
clinical practice guidelines on the management of hepatitis B virus infection. J Hepatol 2017;67:370-398.

14. Terrault NA, Lok AS, McMahon BJ, et al. Update on prevention, diagnosis, and treatment of chronic hepatitis B: AASLD 2018 hepatitis B guidance. Hepatology 2018;67:1560-1599.

15. Lu J, Zhang S, Liu Y, et al. Effect of peg-interferon $\alpha-2 \mathrm{a}$ combined with adefovir in HBV postpartum women with normal levels of ALT and high levels of HBV DNA. Liver Int 2015;35:1692-1699.

16. Giles M, Visvanathan K, Lewin S, et al. Clinical and virological predictors of hepatic flares in pregnant women with chronic hepatitis B. Gut 2015;64:1810-1815.

17. Wegmann TG, Lin H, Guilbert L, Mosmann TR. Bidirectional cytokine interactions in the maternal-fetal relationship: is successful pregnancy a TH2 phenomenon? Immunol Today 1993;14:353-356.

18. Xu C, Mao D, Holers VM, Palanca B, Cheng AM, Molina H. A critical role for murine complement regulator crry in fetomaternal tolerance. Science 2000;287:498-501.

19. Aluvihare VR, Kallikourdis M, Betz AG. Regulatory T cells mediate maternal tolerance to the fetus. Nat Immunol 2004;5:266-271.

20. Faas MM, de Vos P. Uterine NK cells and macrophages in pregnancy. Placenta 2017;56:44-52.

21. Kramvis A, Kostaki EG, Hatzakis A, Paraskevis D. Immunomodulatory function of $\mathrm{HBeAg}$ related to short-sighted evolution, transmissibility, and clinical manifestation of hepatitis B virus. Front Microbiol 2018;9:2521.
22. Lin HH, Chen PJ, Chen DS, et al. Postpartum subsidence of hepatitis B viral replication in $\mathrm{HBeAg}$-positive carrier mothers. J Med Virol 1989;29:1-6.

23. Saito S, Nakashima A, Shima T, Ito M. Th1/Th2/Th17 and regulatory T-cell paradigm in pregnancy. Am J Reprod Immunol 2010;63:601-610.

24. Mor G, Aldo P, Alvero AB. The unique immunological and microbial aspects of pregnancy. Nat Rev Immunol 2017;17:469-482.

25. Wang GQ, Ding YP, Dong YH. Telbivudine treatment is associated with high hepatitis $\mathrm{B}$ e antigen seroconversion and immune modulatory effects in chronic hepatitis B patients. J Viral Hepat 2013;20 Suppl 1:9-17.

26. Swain SL, McKinstry KK, Strutt TM. Expanding roles for $\mathrm{CD}^{+} \mathrm{T}$ cells in immunity to viruses. Nat Rev Immunol 2012;12:136-148.

27. Wu ZG, Yan WM, Guo W, et al. Telbivudine preserves T-helper 1 cytokine production and downregulates programmed death ligand 1 in a mouse model of viral hepatitis. J Viral Hepat 2010;17(Suppl 1):24-33.

28. Park JJ, Wong DK, Wahed AS, et al. Hepatitis B virus: specific and global T-cell dysfunction in chronic hepatitis B. Gastroenterology 2016;150:684-695.

29. Ma XJ, Chen XF, Chen WL, et al. Study on the distribution of CD8+ memory T cell subsets and IFN- $\gamma$ level during the spontaneous clearance of hepatitis B virus in patients with chronic hepatitis B virus infection. Eur Rev Med Pharmacol Sci 2017;21:4675-4679. 